\title{
Determination of sun protection factor (SPF) of sunscreens by ultraviolet spectrophotometry
}

\author{
Elizângela Abreu Dutra, Daniella Almança Gonçalves da Costa e Oliveira, Erika Rosa Maria Kedor- \\ Hackmann*, Maria Inês Rocha Miritello Santoro
}

Departamento de Farmácia, Faculdade de Ciências Farmacêuticas, Universidade de São Paulo

*Correspondence:

E. R. M. Kedor-Hackmann

Departamento de Farmácia

Faculdade de Ciências Farmacêuticas UPS

Av. Prof. Lineu Prestes, 580 - Bloco 13 Cidade Universitária

05508-900 - São Paulo - SP - Brazil

E-mail: ermkedor@usp.br
The aim of this research was to determine the sun protection factor (SPF) of sunscreens emulsions containing chemical and physical sunscreens by ultraviolet spectrophotometry. Ten different commercially available samples of sunscreen emulsions of various manufactures were evaluated. The SPF labeled values were in the range of 8 to 30. The SPF values of the $30 \%$ of the analyzed samples are in close agreement with the labeled SPF, 30\% presented $S P F$ values above the labeled amount and $40 \%$ presented SPF values under the labeled amount. The proposed spectrophotometric method is simple and rapid for the in vitro determination of SPF values of sunscreens emulsions.

\section{INTRODUCTION}

The rapid growth of commercially available products containing sunscreens indicates that even though a suntan is still desired, people are conscious of the possible dangers of photoaging and skin cancer, occurring as a result of sun overexposure.

Every year, about one million people are diagnosed with skin cancer and about 10.000 die from malignant melanoma. Most skin cancer occurs on the areas of the body that are most frequently exposed to the sun, such as the face, neck, head and back of the hands (SAX, 2000).

The harmful effects of solar radiation are caused predominantly by the ultraviolet (UV) region of the electromagnetic spectrum, which can be divided into three regions: UVA, from 320 to $400 \mathrm{~nm}$; UVB, from 290 to 320 $\mathrm{nm}$ and UVC, from 200 to $290 \mathrm{~nm}$. UVC radiation is filtered by the atmosphere before reaching earth. UVB radiation is not completely filtered out by the ozone layer and is responsible for the damage due to sunburn. UVA radiation reaches the deeper layers of the epidermis and dermis and provokes the premature aging of the skin. Ultraviolet radiations have been implicated as a causative factor of skin cancer.

Due to these facts, sunscreens substances are now incorporated into everyday products such as moisturizers, creams, lotions, shampoos, mousses, and other hair and skin preparations.

The regular use of these products may help to reduce the chance of the harmful effects of ultraviolet radiation. However, it is necessary that a very efficient sunscreen substance is used in the cosmetic formulation.

The efficacy of a sunscreen is usually expressed by the sun protection factor (SPF), which is defined as the UV energy required to produce a minimal erythema dose (MED) on protected skin, divided by the UV energy required to produce a MED on unprotected skin (Equation 1): 


$$
\mathrm{SPF}=\frac{\text { minimal erythema dose in sunscreen-protected skin }}{\text { minimal erythema dose in nonsunscreen-protected skin }}
$$

The minimal erythemal dose (MED) is defined as the lowest time interval or dosage of UV light irradiation sufficient to produce a minimal, perceptible erythema on unprotected skin (Wood et al., 2000; Wolf et al., 2001).

The higher the SPF, the more effective is the product in preventing sunburn. Nevertheless, it is necessary to standardize methods to determine the SPF of these products.

The photoprotection afforded by topical sunscreens against solar ultraviolet radiation exposure can be determined in vivo or in vitro, and it is ideally determined by phototesting in human volunteers. This type of determination has been used for many years and although useful and precise, is a time consuming process, complex and expensive, particularly when information concerning to the protection against long wavelength (UVA) is required (Azevedo et al., 1999; Gasparro et al., 1998). As a consequence, much effort has been devoted to the development of in vitro techniques for assessing the photoprotection of sunscreen compounds.

The methods in vitro are in general of two types. Methods which involve the measurement of absorption or the transmission of UV radiation through sunscreen product films in quartz plates or biomembranes, and methods in which the absorption characteristics of the sunscreens agents are determined based on spectrophotometric analysis of dilute solutions (Fourneron et al., 1999; Gordon, 1993; Mansur et al., 1986; Pissavini, M. et al., 2003; Walters et al., 1997).

Mansur et al. (1986), developed a very simple mathematical equation which substitutes the in vitro method proposed by Sayre et al., (1979), utilizing UV spectrophotometry and the following equation:

$S P F_{\text {spectrophootometric }}=C F \times \sum_{290}^{320} E E(\lambda) \times I(\lambda) \times A b s(\lambda)$

Where: EE (1) - erythemal effect spectrum; I (1) solar intensity spectrum; Abs (1)- absorbance of sunscreen product ; $\mathrm{CF}$ - correction factor $(=10)$. It was determined so that a standard sunscreen formulation containg $8 \%$ homosalate presented a SPF value of 4, determined by UV spectrophotometry (Mansur et al., 1986).

The values of EE x I are constants. They were determined by Sayre et al. (1979), and are showed in Table I.

The aim of this research was to determine the SPF values of sunscreens emulsions containing chemical and physical sunscreens by UV spectrophotometry applying Mansur mathematical equation (Equation 2).
TABLE I - Normalized product function used in the calculation of SPF (Sayre et al., 1979)

\begin{tabular}{cc}
\hline Wavelength $(\boldsymbol{\lambda} \mathbf{~ n m})$ & EE x I (normalized) \\
\hline 290 & 0.0150 \\
295 & 0.0817 \\
300 & 0.2874 \\
305 & 0.3278 \\
310 & 0.1864 \\
315 & 0.0839 \\
320 & 0.0180 \\
Total & 1 \\
\hline
\end{tabular}

EE - erythemal effect spectrum; I - solar intensity spectrum

\section{MATERIALS AND METHODS}

\section{Reagents and samples}

Ethanol $\left(\right.$ Merck $\left.^{\circledR}\right)$ analytical grade.

Commercially available sunscreen emulsions of various manufactures were purchased from local pharmacies. The samples are showed in Table II.

\section{Apparatus}

Beckman DU-70 UV/Visible spectrophotometer, equipped with $1 \mathrm{~cm}$ quartz cell, computer and printer Epson FX-850.

\section{Methods}

\section{Sample preparation}

$1.0 \mathrm{~g}$ of all samples was weighed, transferred to a $100 \mathrm{~mL}$ volumetric flask, diluted to volume with ethanol, followed by ultrasonication for $5 \mathrm{~min}$ and then filtered through cotton, rejecting the ten first mL. A $5.0 \mathrm{~mL}$ aliquot was transferred to $50 \mathrm{~mL}$ volumetric flask and diluted to volume with ethanol. Then a $5.0 \mathrm{~mL}$ aliquot was transferred to a $25 \mathrm{~mL}$ volumetric flask and the volume completed with ethanol.

The absorption spectra of samples in solution were obtained in the range of 290 to $450 \mathrm{~nm}$ using $1 \mathrm{~cm}$ quartz cell, and ethanol as a blank. The absorption data were obtained in the range of 290 to 320 , every $5 \mathrm{~nm}$, and 3 determinations were made at each point, followed by the application of Mansur equation. 
TABLE II - SPF labeled and found in the commercially available samples

\begin{tabular}{|c|c|c|c|c|}
\hline $\begin{array}{c}\text { Commercial sample } \\
\text { (function) }\end{array}$ & Active Ingredient & $\begin{array}{c}\text { Amount } \\
(\%)\end{array}$ & Labeled SPF & Found SPF* \\
\hline $\begin{array}{c}\mathrm{A} \\
\text { (Emulsion for body) }\end{array}$ & $\begin{array}{l}\text { benzophenone-3 } \\
\text { octyl methoxycinnamate }\end{array}$ & $\begin{array}{l}4.0 \\
7.5\end{array}$ & 15.00 & $16.24 \pm 0.05$ \\
\hline $\begin{array}{c}\text { B } \\
\text { (Emulsion for body) }\end{array}$ & $\begin{array}{l}\text { benzophenone-3 } \\
\text { octyl methoxycinnamate }\end{array}$ & $\begin{array}{l}3.0 \\
8.0\end{array}$ & 15.00 & $15.35 \pm 0.06$ \\
\hline $\begin{array}{c}\mathrm{C} \\
\text { (Emulsion for body) }\end{array}$ & $\begin{array}{c}\text { benzophenone-3 } \\
\text { octyl methoxycinnamate } \\
\text { titanium dioxide and alkylbenzoate }\end{array}$ & $\begin{array}{l}2.8 \\
6.8 \\
0.7\end{array}$ & 15.00 & $14.90 \pm 0.03$ \\
\hline $\begin{array}{c}\mathrm{D} \\
\text { (Emulsion for body) }\end{array}$ & $\begin{array}{l}\text { benzophenone-3 } \\
\text { octyl methoxycinnamate } \\
\text { octyl salicylate } \\
\text { titanium dioxide }\end{array}$ & $\begin{array}{l}3.5 \\
7.0 \\
2.0 \\
2.0\end{array}$ & 15.00 & $14.65 \pm 0.04$ \\
\hline $\begin{array}{c}\text { E } \\
\text { (Sunblock lotion) }\end{array}$ & $\begin{array}{c}\text { benzophenone-3 } \\
\text { octyl methoxycinnamate } \\
\text { titanium dioxide and alkylbenzoate }\end{array}$ & $\begin{array}{l}2.1 \\
5.7 \\
0.6\end{array}$ & 8.00 & $12.20 \pm 0.06$ \\
\hline $\begin{array}{c}\mathrm{F} \\
\text { (Emulsion for body) }\end{array}$ & $\begin{array}{l}\text { benzophenone-3 } \\
\text { octyl methoxycinnamate } \\
\text { octyl salycilate } \\
\text { titanium dioxide }\end{array}$ & $\begin{array}{l}1.5 \\
5.5 \\
1.0 \\
1.0\end{array}$ & 8.00 & $10.94 \pm 0.04$ \\
\hline $\begin{array}{c}\mathrm{G} \\
\text { (Emulsion for body) }\end{array}$ & $\begin{array}{l}\text { benzophenone-3 } \\
\text { octyl methoxycinnamate } \\
\text { octyl salycilate } \\
\text { titanium dioxide }\end{array}$ & $\begin{array}{c}2.75 \\
6.5 \\
1.0 \\
1.0\end{array}$ & 15.00 & $13.65 \pm 0.04$ \\
\hline $\begin{array}{c}\mathrm{H} \\
\text { (Emulsion for body) }\end{array}$ & $\begin{array}{l}\text { benzophenone- } 3 \\
\text { octyl methoxycinnamate } \\
\text { octyl salycilate }\end{array}$ & $\begin{array}{l}5.0 \\
7.5 \\
5.0\end{array}$ & 30.00 & $19.00 \pm 0.07$ \\
\hline $\begin{array}{c}\text { I } \\
\text { (Emulsion for body) }\end{array}$ & $\begin{array}{l}\text { benzophenone-3 } \\
\text { octyl methoxycinnamate; } \\
\text { titanium dioxide and zinc oxide }\end{array}$ & Not specified & 20.00 & $14.15 \pm 0.04$ \\
\hline $\begin{array}{c}\mathrm{J} \\
\text { (Emulsion for face) }\end{array}$ & $\begin{array}{l}\text { benzophenone- } 3 \\
\text { octyl methoxycinnamate } \\
\text { octyl salycilate }\end{array}$ & Not specified & 23.00 & $20.3 \pm 0.05$ \\
\hline
\end{tabular}

* Experimental data obtained in this research. $M=6$

\section{RESULTS AND DISCUSSION}

The SPF is a quantitative measurement of the effectiveness of a sunscreen formulation. To be effective in preventing sunburn and other skin damage, a sunscreen product should have a wide range of absorbance between 290 and $400 \mathrm{~nm}$. Evaluation of the efficiency of a sunscreen formulation has for a long time been assessed through in vivo test, which is performed with human volunteers. In vivo test is time- consuming, is normally 
subject to certain degree of variability, not mention the ethical problems of testing with human. The in vitro SPF is useful for screening test during product development, as a supplement of the in vivo SPS measure.

In this research ten different commercially available sunscreen products were evaluated by UV spectrophotometry applying Mansur mathematical equation (Mansur et al., 1986). The SPF labeled values were in the range of 8 to 30 . These products and SPF values of samples obtained using the UV spectrophotometric method were shown in Table II. It can be observed that the SPF values found for samples B, C and D are in close agreement with the labeled SPF. Samples A, E and F presented SPF values above the labeled amount. All other samples presented SPF values under the labeled amount.

Among samples analyzed, sample $\mathrm{H}$ exhibits a maximal absorbance higher than all samples with known amounts of sunscreens, as it can be observed in Table II. This is provably due to the fact that sample $\mathrm{H}$ has a total amount of sunscreen substance higher than the other samples, presenting thus, a SPF higher than the calculated.

Samples D and G present the same SPF values labeled $(\mathrm{SPF}=15.0)$. They present the same sunscreens, but at different concentrations. Sample G has less total amount of sunscreens than sample $\mathrm{D}$, what was reflected in the obtained SPF values. Sample G presented a calculated SPF value smaller than the one of sample D.

Data variation can be due to the use of non validated spectrophotometric methodology being used for determination of the absorption characteristics of the sunscreens agents. However, there are many factors affecting the determination of SPF values, as for example, the use of different solvents in which the sunscreens are dissolved; the combination and concentration of the sunscreens; the type of emulsion; the effects and interactions of vehicle components, such as esters, emollients and emulsifiers used in the formulation; the interaction of the vehicle with the skin; the addition of other active ingredients; the $\mathrm{pH}$ system and the emulsion rheological properties, among other factors, which can increase or decrease UV absorption of each sunscreen. The effect that different solvents and emollients have upon the wavelenght of maximum absorbance and upon the UV absorbance of several sunscreens chemical, alone or in combination is well known and documented (Riegelman et al.,1960; Agrapidis-Paloympis et al., 1987). Excipients and other active ingredients can also produce UV absorption bands, thus interfering with those of UVA and UVB sunscreen. This effect is reflected in a finished formulation, especially for lotions with an SPF greater than 15 . The effect of a solvent is only realized at high percentages.
According to Pissavini et al. (2003), a high SPF values are more difficult to measure. A high SPF normally leads to a greater uncertainty also in the final in vivo result, due to the biological variations of the volunteers.

Therefore, to develop sunscreens with better safety and high SPF, the formulator must understand the physicochemical principle, not only the UV absorbance of the actives, but also vehicle components, such as esters, emollients and emulsifiers used in the formulation, since sunscreens can interact with other components of the vehicle, and these interactions can affect sunscreens efficacy.

\section{CONCLUSIONS}

The proposed UV spectrophotometric method is simple, rapid, employs low cost reagents and can be used in the in vitro determination of SPF values in many cosmetic formulations. The proposed methodology may be useful as a rapid quality control method. It can be used during the production process, in the analysis of the final product, and can give important information before proceding to the in vivo tests.

\section{ACKNOWLEDGEMENTS}

The authors wish acknowledge the "Fundação de Amparo à Pesquisa do Estado de São Paulo (FAPESP)", Brazil (Process 98/05069-7) for the financial support.

\section{RESUMO}

\section{Determinação do fator de proteção solar (FPS) de protetores solares por espectrofotometria no ultravioleta}

O objetivo desta pesquisa foi determinar o Fator de Proteção Solar (FPS) de emulsões contendo filtros solares físicos e químicos por espectrofotometria no ultravioleta. Foram analisadas dez amostras comerciais de emulsões de diferentes fabricantes. Os valores de FPS rotulados foram na faixa de 8 a 30. Das emulsões analisadas, 30\% apresentaram valores de FPS próximos do valor rotulado, $30 \%$ apresentaram valores acima e $40 \%$ apresentaram valores abaixo do valor rotulado. O método espectrofotométrico proposto é simples e rápido para determinação preliminar in vitro do FPS de emulsões protetoras solar.

UNITERMOS: Filtros solares. Produtos cosméticos. Fator de proteção solar. Espectrofotometria no UV. 


\section{REFERENCES}

AGRAPIDIS-PALOYMPIS, L. E.; NASH, R.B.; SHAATH, N.A. The effect of solvents on the ultraviolet absorbance of sunscreens. J. Soc. Cosmet. Chem., New York, v. 38, p. 209-221, 1987.

AZEVEDO, J. S.; VIANA JUNIOR, N. S.; SOARES, C. D. V. UVA/UVB sunscreen determination by second-order derivative ultraviolet spectrohotometry. Farmaco, Pavia, v. 54, p.573-578, 1999.

FOURNERON, J. D.; FARAUD, F.; FAUNERON, A. Sur la mesure in vitro de la protection solaire de crèmes cosmétiques. C. R. Acad. Sci. II, Paris, v. 2, p. 421-427, 1999.

GASPARRO, F. P.; MITCHNICK, M.; NASH, J.F. A review of sunscreen safety and efficacy. Photochem. Photobiol., Oxford, v. 68, p. 243-256, 1998.

GORDON, V.C. Evaluation du facteur de protection solaire. Parfum. Cosmet. Arom., Paris, n. 112, p.62-65, 1993.

MANSUR, J. S.; BREDER, M. N. R.; MANSUR, M. C. A.; AZULAY, R. D. Determinação do fator de proteção solar por espectrofotometria. An. Bras. Dermatol., Rio de Janeiro, v. 61,p. 121-124, 1986.
PISSAVINI, M.; FERRERO, L.; ALARO, V.; HEINRICH, U.; TRONNIER, H.; KOCKOTT, D.; LUTZ, D.; TOURNIER, V.; ZAMBONIN, M.; MELONI, M. Determination of the in vitro SPF. Cosmet. Toiletries, Oak Park, v. 118, p. 63-72, 2003.

RIEGELMAN, S.; PENNA, R.P. Effect of vehicle components on the absorption characteristics of sunscreens compounds. J. Soc. Cosmet. Chem., New York, v. 11, p. 280-291, 1960.

SAX, B. W. Educating Consumers about sun protection. Pharm. Times, New York, v. 66, n.5, p. 48-50, 2000.

SAYRE, R. M.; AGIN, P. P.; LEVEE, G. J.; MARLOWE, E. Comparison of in vivo and in vitro testing of sunscreening formulas. Photochem. Photobiol., Oxford, v. 29, p. 559-566, 1979.

WALTERS, C.; KEENEY, A.; WIGAL, C. T.; JOHNSTOM, C. R.; CORNELIUS, R. D. The spectrophotometric analysis and modeling of sunscreens. J. Chem. Educ., Washington, v. 74, p. 99-102, 1997.

WOLF, R.; WOLF, D.; MORGANTI, P.; RUOCCO, V. Sunscreens. Clinic. Dermatol., New York, v. 19, p. 452-459, 2001.

WOOD, C.; MURPHY, E. Sunscreens efficacy. Glob. Cosmet. Ind., Duluth, v. 167, p. 38-44, 2000.

Recebido para publicação em 16 de março de 2004. Aceito para publicação em 13 de setembro de 2004. 